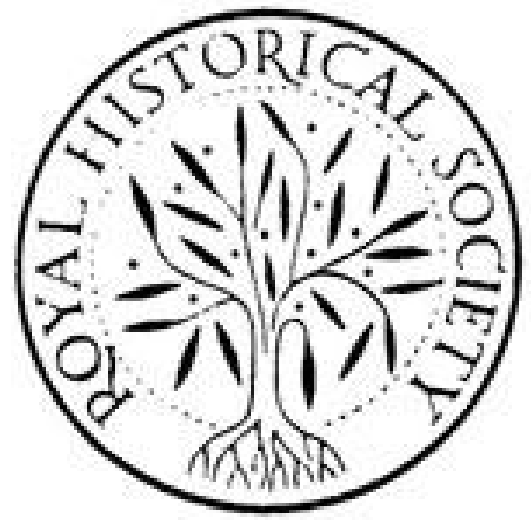

The Free Grammar School of Bristol, and the Thorns, Its Founders Author(s): J. F. Nicholls

Source: Transactions of the Royal Historical Society, Vol. 1 (1872), pp. 311-323

Published by: Cambridge University Press on behalf of the Royal Historical Society Stable URL: http://www.jstor.org/stable/3677912

Accessed: 26-06-2016 13:45 UTC

Your use of the JSTOR archive indicates your acceptance of the Terms \& Conditions of Use, available at

http://about.jstor.org/terms

JSTOR is a not-for-profit service that helps scholars, researchers, and students discover, use, and build upon a wide range of content in a trusted digital archive. We use information technology and tools to increase productivity and facilitate new forms of scholarship. For more information about JSTOR, please contact support@jstor.org.

Cambridge University Press, Royal Historical Society are collaborating with JSTOR to digitize, preserve and extend access to Transactions of the Royal Historical Society 


\title{
THE FREE GRAMMAR SCHOOL OF BRISTOL, AND THE THORNS, ITS FOUNDERS.
}

\author{
BY J. F. NICHOLLS, ESQ.
}

ICELAND, which lies but ninety-five miles distant from the nearest part of the American continent, was well known to the merchants of Bristol, who traded thither in the early part of the fifteenth century.

During William Cannynge's second Mayoralty in 1450, King Henry VI. specially exempted that distinguished merchant by name in a treaty made with Denmark, which prohibited all other Englishmen from trading with Iceland.*

That the hardy mariners who traversed these seas should have found no floating signs of a more westerly land is scarcely conceivable. Something upon which they could base a theory there must have been, for in 1480 John Jay, jun., a merchant of Bristol, despatched two ships under the command of T. Llyde, said to be then the most scientific seaman in England, in search of a country far to the west of Iceland + For nine weary months Llyde cruised about the Atlantic in vain.

Pedro de Ayala, the Spanish ambassador to England, in no friendly spirit towards her maritime enterprise, informs his master that for seven years previous to $\mathbf{1} 490$ the Bristol men had been in the habit of sending out annually from two to four ships in search of the mythical island of Brazil. $\neq$ Columbus's discovery of the Western Indies, and Cabot's of the Northern Continent followed, and the theories of men who had been treated as visionaries were verified.

Several patents for colonization and for trade were immediately granted by Henry VII. to sundry merchants of Bristol. Among these early speculators, or rather, to use his son's words, "one of

* Rymer's “Fœdera," tom. xi., p. 226.

+ William Worcester, pp. 153-185.

† "Spanish Calendars," pp. 177. 
those who had set forth the expedition of England," was Robert Thorn, a Spanish oil merchant and soapmaker, and a wealthy member of the woollen cloth trade in Bristol. He was a descendant of Rollo, Duke of Normandy, and his family claimed consanguinity with the noblest in the kingdom.* In I $^{1} 5$ he became Mayor of Bristol, and in $\mathbf{r}_{523} 3$ he represented the borough in Parliament.

Though the King had called the Commons together " to remedy mischiefs in the common law, and to make new laws for the government of the Commonwealth," nothing of the kind was effected. Henry attempted to force a subsidy of $£ 800,000$, at the rate of 4 s. in the pound upon every man's goods or lands, but "the burgesses were all against it," and the people threatened that they should not go home alive if they gave way.

During his attendance on this Parliament, Robert Thorn died in 1523, and was buried in the Temple Church, London, wherein, Hakluyt says, stood his monument, bearing a Latin inscription of which the following is a literal translation: $†-$

"Here lies Robert Thorn, whom sometime the City of Bristol deservedly selected to discharge the office of Mayor, for the commonwealth was always an object of great care to him, and his native land was dearer than all wealth.

To give aid to the helpless, to allay the bitterness of private strife

To help every one with his prudent counsels was always his delight.

Do Thou, O Christ, who graciously hearest the prayer and vows of the distress'd

Grant to him a place in the Country of Heaven.

"By will he devised certain property for the erection, foundation, continuance, and supportation, of a Free School of Grammar to be established in Bristol." $\ddagger$

He left two sons, Robert and Nicholas, who with John Goodryche were his executors. Master Goodryche was one of those Priors who afterwards preached against Latimer, when in $1526-7$ he denounced Purgatory, \&c., in the streets of Bristol. §

At the time of his father's death Robert Thorn, jun., was residing in Spain. Born and bred in Bristol, he had become a Merchant Tailor of London, but his great wealth was accumulated at Seville,

" "History of the Thorn Tree and Bush," p. 62.

$¥$ Nicholas Thorn's Deed Poll, Ist July, 156r.

† Hakluyt, p. 220.

$\S$ Seyer, vol, ii., p. 217. 
where he lived in friendly intimacy with the most scientific seamen and geographers of his day. When a boy in Bristol he might have seen the triumphant return of Sebastian Cabot from his grand discovery - in the fitting out of whose expedition his father had probably borne a share, as well as in that under the patent of $I 5^{\circ} \mathrm{I}$ with Hugh Elliott; certain it is that Thorn was on the most friendly terms with his great townsman, who held then the post of Pilot Major in Spain Americus Vesputius, Columbus, jun., and Peter Martyr, were also his familiar friends.

Cabot was at this time projecting a new expedition to the Indies by a south-westerly course. Baffled for a time by the intrigues of Portugal, and the scarcity of funds, he finally sailed in ${ }^{2} 5^{26}$ on his famous expedition to the Rio de la Plata.*

To fit out this expedition, and to advance the interests of science, Robert Thorn and his partner advanced I,400 ducats, or more than one-seventh part of the whole cost. $\dagger$ "A small caravel added to the squadron by an individual" belonged also to Thorn, as he tells us that "two English friends of mine (George Barlow being one), who were learned in cosmography," were sent by him to bring him a relation of the countries, and to acquire expertness in the art of navigation. +

But it was not merely by a liberal devotion of his wealth to the cause of scientific discovery that Thorn maintained his position amongst the great cosmographers of the age. His letters to Henry VIII., and to Dr. Ley, the English ambassador to Spain, bespeak him as their peer in ability, clearness of foresight, calmness of judgment, and scientific acquirements. $\S$

To the doctor he sends accounts of the conflicting claims to discoveries in Spain and Portugal; discriminates between those which are real and those which are assumed; shows the extent and position of the former; draws with his own hand charts to be used by the mariners, and points out the kind and value of the commerce. Nor is this all; he pencils out his own ideas upon the chart, gives a north-west and westerly coast-line to America from Hudson's Bay, as the probable shape of that end of the continent, and presents both latitude and longitude, with directions how to find

* Peter Martyr, Dec. VII., cap. vi.

$\ddagger$ Ibid, Herrera, Dec. IV., lib. iii., cap. i.

$\uparrow$ Hakluyt, 215.

$\S$ Hakluyt, pp. 212-220. 
them. He suggests routes which shall verify his theory-that the newfound land (America), then thought to be insular, is really continental, and contends that had it not been for the cowardice of the mariners, the expedition in which his father was a partner many years before might have gone by the N.W. to California and Peru. This theory has been verified by $\mathrm{McCl}$ ure, McClintock, and Collinson, in this nineteenth century.

Neither can Robert Thorn, good Catholic as he undoubtedly is, allow the right which the Pope claimed to dispose of at his will all the nations upon the earth. In the dispute between Spain and Portugal his Holiness had drawn a longitudinal line, and so divided the heathen world between the two nations. "Christ said," says Thorn, "Quis me constituit judicem inter vos,' but the Pope did not refuse, but making himself as Lord and Judge over all, not only granted that all lands that should be discovered from the Orient to the Occident should be the King's of Portugal, but also that upon great censures no other Prince should discover but he." *

Many months before this, Thorn had written direct to Henry VIII. upon the same subject, and boldly and earnestly does he press the policy of an exploring expedition from England upon the King.t Spain has discovered the West Indies, Portugal the East, it is your duty to explore the north, because the situation of your realm is nearest and aptest of all others; because the almost continued daylight of the northern seas renders navigation less dangerous there than it is in the regions where ordinary dark nights prevail ; because your Grace's subjects have begun the work; and besides by it your Grace shall win perpetual glory, and your subjects infinite profit without having to travel half as far as the Spaniards; for if our men do go by the back of the new-found land discovered by Cabot, they shall reach under the equinoctial the richest lands and islands of the world. Further, people would think that he, the King, lacked the noble courage and spirit of other princes if he were content to live quiet in his own dominions, \&c., \&c." The King was stirred and so determined on the attempt, and in May, 1527, the Mary of Guildford and the Samson set sail from the Thames. The Samson with all on board was lost in a terrific storin

* Hakluyt, $217 . \quad+$ Hakluyt, 212. 
on the coast of Labrador. The Mary, commanded by Rut, escaped and coasted the land to the southward, losing her pilot, the celebrated Verrazani, who, having gone on shore, was killed by the natives, and roasted and eaten in the sight of those who remained on board the ship.* Though the expedition failed in its object, Thorn, who had now returned to England, did not suffer any loss of favour from the King-for in the year following he obtained from Henry letters of licence to purchase of the brethren and sisters their Hospital of St. Bartholomew.

This religious foundation was originally a lazar-house for lepers. Chatterton correctly describes it as being subject to annoyance from the overflowing of the river Frome, on whose bank it stood. On the left side of its entrance porch still stands the mutilated statue of the Virgin and Child; but the statue of the mailed warrior, which he mentions as guarding the opposite side, has disappeared. $\dagger$ Leland, who visited Bristol about 1533, tells us "the Bartilmews" was in ruins.

Having licence from the King, George Croft the Master, and Sir Thomas West and Lord La Warr, the patrons gladly sold the whole estate to Robert Thorn, jun., Nicholas Thorn and John Goodryche, who, as executors of the elder Thorn, now began to carry out the testator's wishes. $\ddagger$

The property, situated in the town of Bristol, and in the parishes of Clifton, Stapleton, Sodbury, Horfield, and Wickwar, consisted, besides the Hospital, of five messuages, 80 acres of meadow, 200 acres of pasture, and ro of woodland, besides 40 . rent in King's Marsh.

Robert Thorn the elder's desire had been that a free grammar school might be erected in Bristol, which should continue therein for ever, and his executors now sought to convey to the mayor, burgesses, and commonalty of the borough the above estate, out of which they were to pay forty pounds clear annually to the support of the school.

Meanwhile, ere matters were settled, Robert Thorn, jun., died, leaving a princely fortune, equal to a quarter of a million in the present day.

Death seized on the son, as he had done the father, while in London, and he was buried in the church of St. Christopher, where

- Purchas, vol. iii., p. 809 ; Ramusi, tom. iii., fol. 417.

† Barrett's “" History of Bristol," p. 428. \pm N. Thorn's Deed Poll. 
Stow tells us "there was a monument of pure touch," containing a Latin epitaph rendered as follows :*-

"Here reposes Robert Thorn an honourable merchant Who by business gained for himself an honest fortune The city of Bristol had given him life as a boy London had buried him in his tomb before his time

He did honour to his country by his pursuit of learning, and exalted it by his virtues. Of his own accord he erected a public school at his own expense. Whosoever thou art $\mathrm{O}$ Reader that approachest this place ask peace (I pray) for his ashes, and humbly move the Deity to answer thy prayer."

Fuller, in his Worthies, quaintly says, "I see it matters not what the name be, so the nature be good. Thorns came in by man's curse, and our Saviour says, 'Do men gather grapes of thorns?' But this our Thorn (God send us many copies of them) was a blessing to our nation. Wine and oil may be freely said to flow from him; being bred a merchant tailor, he gave more than $£ 4,445$ to pious uses, a sum more than sufficient to endow a college. I have observed some at the church door cast in sixpence with such ostentation, that it rebounded from the bottom, and rang against both sides of the basin (so that the same silver was the alms and the giver's trumpet), whilst others have dropped down five shillings without noise. Our Thorn was of the second sort, doing his charity effectually, but with all possible privacy. Nor was this good Christian abroad, worse (in the apostolic phrase) than an infidel at home in not providing for his family, who gave his poor kindred, besides debts forgiven unto them, $£ 5$, i42. Grudge not, reader, to peruse his epitaph, which, though not so good as he deserved, is better than most in that age." $\dagger$

From his Will preserved in the great Will-Book in the Councilhouse, Bristol, we gather that among the charitable donations were the following: $£ 300$, and more that my Lord Delawar oweth-toward the making up of St. Bartholomew's School, Bristol ; $£ 300$ to buy corn and wood when it is cheap, the same to be sold at the cost price to the poor when provision and firewood are dear; $£ 500$ to lend free of interest to young men beginning business as clothiers in Bristol; $£ 50$ to the relief of poor prisoners in London, and a like sum for the same purpose in Bristol ; $£ 50$ towards the marriages of poor maidens in Bristol; $£$ roo to be given in bread to the four

* Stow, p. 193. † Fuller's "Worthies of Bristol," p. 36. 
prisons in London, and a like sum to be for the prisons in Bristol; " the bread to be prudently given, any quarter of a year, to any house, until the money be expended ;" $£$ roo to be expended in making in the streets of Bristol a place of merchandise, at the discretion of his executors, on condition that it be made within three years of his decease; $£_{200}$ for the reparation of the highways in and around Bristol ; $£ 500$ to be distributed in good deeds of mercy, to the relief of the commons of Bristol, above his bequests aforesaid; also E200 "towards the redemption of the fee farm and prisay of the said town of Bristol, so that it be redeemed within these three years ;" and $£_{500}$ to be distributed among the 25 wards of London, $£^{20}$ in each ward to poor householders. To Thomas Moffatt, the master of the Free Grammar School $£_{25}$; and to his son Robert Moffatt, E10. He forgives the various debts of his relatives and friends, the sums specified vary from $£_{500}$ down to $£_{4}$ I 5 s. ; " all these foresaid debts I forgive and bequeath to any of them, and would not that it be asked." To each of the five almshouses in Bristol he bequeaths £roo.

In the bequests to relatives is one of $£ \mathrm{I}, 000$ " to my son Vincent Thorn, being in Spain, which I will that Carolo Catanio, that hath the keeping of him at this present in Spain, shall receive out of the goods of mine that the said Carolo Catanio and his brother hath to the use and benefit of my said child till he be of lawful age ; and if the said Vincent my son die before he come to lawful age, the said $£_{3,000}$ to return to my heirs. Item I also bequeath to Anayaria, mother of the said Vincent, $£ 50$, with condition that she renounce all that pretence of inheritance of the bequest of her said son." It would appear that the above $£ 3,000$ had been left in trust to maintain the boy and his mother when Thorn left Spain. He mentions two chests of Geant velvet, in the which are 33 pieces black, appertaining to George Catanio, more two helles of pearles worked with a spectacles in the which is 200 pearles that are also the said George's."

The above are the principal bequests; besides which he makes his brother Nicholas his residuary legatee, willing further, however, that there shall be " in the powers of my executors, one thousand pounds, to be distributed and ordered as they shall see best for my soul. The will was subscribed and sealed on the $23^{\text {rd }}$ of May,

- Great Will Book, Bristol Archives. 
I532, and was proved in London on the roth of October in the same year.*

Robert Thorn, jun., never sought municipal or parliamentary honours; his portrait by Holbein, I $53^{\circ}$, gives his age correctly as thirty-eight and represents a jolly, bluff-looking, open countenance which bears a most striking likeness to that of King Henry VIII. His arms are given in the dexter corner; in the sinister is a Latin distich to this effect: -

"I am called a Thorn; the glory be given to God who giveth the good things that the Thornes dispense to the poor." $\dagger$

It was a happy thing for Bristol that the elder Thorn's wishes were carried into effect by his large-hearted and educated son.

The age was growing barren of writers in the Latin tongue; the study of Greek introduced into England and Oxford in the elder Thorn's day by Grocyne, a Bristol man, was even now powerfully assailed in both universities by the Trojans. + Thorn's object was to resuscitate classical literature by cultivating a taste for, and educating the children of his fellow citizens up to an appreciative enjoyment of its beauties. Hence his foundation of what we now term a first grade classical school, in which should be given, "for learning and knowledge of the Latin tongue, and other good learning, to teach grammar and understanding of the tongues, and other good literatures, to all children and others that would repair to the said school, \&c., freely without anything to be taken, other than fourpence only for the first admission of every scholar." $\$$

With a mind well cultivated and enlarged by intimate converse with the highest intellects of the age, Thorn's classical tastes gave an impress to the Free Grammar School, which amidst varied changes it has ever borne, but never more honourably or beneficially to Bristol than at the present time.

Henry VIII. will ever need and but seldom obtain a champion; it is only just to say that he has been falsely accused of robbing the Hospital of Bartholomew, to give it to the Thorns. The King never benefited by the transfer. The sale of the property was gladly made by the owners eight years before the monasteries were dissolved ; it was paid for by the elder Thorn's bequest, made sixteen

* Great Will Book. † Trustees' House, Queen Square.

† Hallam, "Middle Ages," iii., 595.

\$ Manchee's Charities, p. 31 . 
years before that date. Robert Thorn, jun., also died three years before that period, leaving bequests to the schoolmaster, and to his son, so that the school was at work from $\mathrm{r} 530$ if not before. Let us add that the Thorns were firm adherents of the Romish faith; Robert, jun., kept a priest, and left legacies to the four orders of Friars established in Bristol, so that the accusation that they sought to pave a golden way into heaven with property which they had stolen from their own church is a slander on their memory.

It has been assumed by Manchee and others, that the $£ \mathrm{r}, 000 \mathrm{left}$ at the discretion of the younger Thorn's executors, to be used by them for the good of his soul, was appropriated to the Grammar School. But whatever Thorn, jun., did for the school during his life time (and it was probably considerable), there is no proof of the institution benefiting by his death beyond the sum of $£ 300$ before mentioned.

A window of the parish church of Walthamstow had (perhaps still has) this inscription :- "Christen people, praye for the soule of Robert Thorn, citizen of London, wyth whose goodys thys syde of thys churche was newe edyfied and fynished in the yeare of our Lord I 535." Inasmuch as this took place three years after Thorn's death, the probability is that the work was done* for the good of his soul by his executors, Withypoul, Lucar, and Hubberthorne, who might have been Essex, but certainly were not Bristol men.

Nicholas, who succeeded his brother, was a merchant and large shipowner in Bristol. Under date $\mathrm{r}_{526} 6$ is an invoice of armour and other merchandise sent by him to T. Tison, an English settler in the West Indies; this is the first record we have of traffic with a region which in after years, and to this day, contributes largely to the wealth of Bristol.

In 1534 Henry visited his royal demesne of Thornbury, part of the confiscated possessions of the princely Buckingham. Ten fat oxen for the King, and a silver cup with cover, containing one hundred marks, for Queen Anne Boleyne, were Bristol's compliment to royalty. Henry was so gratified that he and some members of his court came over incog., and was entertained by Nicholas Thorn, to whom, when showing him the town, the King said, "This is now the

* Pryce's " History of Bristol," p. 582. 
town, but I will make it the city of Bristol." * Nicholas served as sheriff in 1529 ; in 1537 he represented the borough in Parliament; and in 1545 he became mayor, three years after it had by letters patent been made a city.

During his mayoralty, Thorn, with others, sent eight large ships to the help of the King in his war with France; the largest of these was the barque Thorn, of 600 tons; when Henry delightedly exclaimed, "I wish I had many such Thorns, Gournays, and Pratts in my land." +

In 1545 the plague being very deadly in the city, Master Thorn, the mayor, held his Admiralty Court at Clevedon; when the pestilence subsided, the five gates of the city were made free for strangers with their goods, and the Quay for all merchandise but salt fish. That year also a printing press was set up in Bristol, and a mint was erected in the castle, wherein the plate confiscated in the monasteries was coined into money. $\ddagger$

Nicholas Thorn is accused, on the authority of a letter dated 1539, of being one of the persecutors of Wishart, who had in that year to do penance, wearing a fagot in St. Nicholas and Christ Church, Bristol. Thorn is by the writer termed a niggard and a knave, and his wife a hypocrite ; he is, moreover, warned that unless he discharge Wishart to sureties, the poyntmakers will rise and crop his ears. $\$$

But Nicholas Thorn was no niggard; he left a large family well provided for; a bequest to an illegitimate child of $£^{66}$ r3s. 4d. ; $£ 400$ to lend out to young clothiers ; $£ 336$ r3s. 4d. to the library at the grammar school ; $£^{6} 3$ r3s. 4d. to maids on their marriage; $£$ 100 for repairing the bridges; and $£_{25}$ for repairing the banks of the river and the public granary. He died on the rgth of August, 1546, and his ashes lie under the pavement of Small Street, Bristol, adjoining the church of St. Werburgh-the end of which was cut off to widen the street. On a monumental cross, removed to its present situation in the church, is this inscription:-

"In this tomb, gentle reader, lies Nicholas Thorn, formerly a famous and upright merchant, whose words were governed by truth, and whose deeds were ruled by justice and virtue. Born in

* Sayer, vol. ii., 214. $\quad+$ Ibid., 227. $\quad$ Evans, 140. \$ Seyer, vol. ii. 223. 
Bristol, there also he died, being more worthy of the gift of everlasting life, for he ruled the city as chief magistrate, and enriched it with a noble school at his own and his brother's expense, and the whole community of Bristol acknowledged him as a munificent father, by whose bounty they were blessed.

"The old and the young, boys and maidens, and the inhabitants at large, weep and lament that he should so soon have been taken from them ; but the Almighty hath seen fit to remove him from these scenes of misery, blest though he was in the affection of his second wife and ten children.

"This tomb contains only his earthly remains; his soul has entered the region of the skies.

"The same tomb contains the ashes of his first beloved wife, and also of their firstborn son."

The portrait of Nicholas, also by Holbein, is extant ; he is a thin, careworn, melancholy-looking man, and under his monogram in the corner is the quaint sentence, "Ex spinis uvas collegimus" (we gather grapes of thorns).*

Amidst the confusion caused by the "wild misrule of Tudor's burly son," and the confiscations of religious property on every hand, it is not to be wondered at that on the death of Nicholas (the last surviving executor of the elder Robert Thorn) the conveyance of the property was still incomplete; "there was no further assurance or establishment of the premises, which descended in that state to his sons, being his heirs, John Harris being the master of the school at a salary of forty marks."

Robert, eldest son of Nicholas Thorn, succeeded to the estate; but ere any settlement could be effected, he, too, died without issue, and the next son, Nicholas Thorn, jun., became the possessor of the property. $\dagger$

For the next fifteen years the property was in abeyance, and it would evidently have been lost to the city but for William Carr, mayor in $156 \mathrm{r}$, by whom Nicholas, jun., was compelled to come to a settlement, which, as a compromise, was perhaps the best thing that could be done. The city retained the school-house, the capital house of the Bartholomews, all edifices within the outer gate, in-

* The portraits of Robert and Nicholas Thorn, which are preserved in the Council House, Bristol, are copies by a Dutch painter, and cost $£ 24$ s. in 1624 The originals are in the Trustees' House, Queen Square.

+ Manchee, p. 30 . 
cluding two small aisles or chapels, but gave up the land, subject to a ground rent of thirty pounds, for the support of the school, and a covenant to keep the buildings in good repair.

Nicholas Thorn, jun., became Chamberlain of the city of Bristol in 1584 , and died in 1603 .*

Pryce, in his "History of Bristol," quotes the elder Nicholas as being Chamberlain; but he had been dead thirty-eight years, and it was his son who was chosen to that office.

Alice Pykes, a widow, inherited the grammar school estate on the death of her father, Nicholas Thorn, jun., but deriving only an income of twenty pounds from it; and having no power to sell, she sought relief in the Court of Chancery.

At a conference between the Chancery commissioners and the Mayor and commonalty, the latter, " in consideration of the good deeds of Alice Pykes' ancestors, of her having seven daughters, and of the better luck which had befallen her sisters, whose land had been well sold, allowed her to sell the property, subject to a rental for the school of $\mathcal{E}_{40}$, and $\mathcal{E}^{\mathrm{I}}$ 6s. 8d. yearly for repairs.

Shortly after this Alderman Whitson bought the estate for the city for $£^{6} 5^{\circ}$; and in $162 \mathrm{I}$ it was at last placed properly in trust.

It will be observed that hitherto there is absolutely no restriction as to eligibility for admission to the school; it was "for all children and others that would repair to the said school for learning, \&c.;" but in 1634 George White gave an exhibition at Oxford of the value of five pounds yearly for the maintenance and support in that university of such poor scholar or scholars who should be sent there from this school, the same being sons of freemen of Bristol.

Mrs. Snigge's two exhibitions of the value of six pounds each, given in 1636 , were hampered with a similar restriction. Alderman Whitson gave, in 1627 , two ten pound exhibitions "towards the maintenance of two poor men's sons at Oxford, or Cambridge, that had first had their education and bringing up in the free grammar school.*

Two scholarships at St. John's, Oxford, were founded by Sir Thomas White, Knight and Alderman of London, in 1566 , which were open to the grammar schools of Coventry, Reading, and Bristol, but which have always fallen to the last.

* Bristol Archives.

+ Ibid. 
In 1783 , by a piece of gross injustice and intrigue, an Act was obtained by which the authorities compelled the city school, Queen Elizabeth's Hospital, to exchange homes with the free grammar school, the master of which, and his wife (an alderman's daughter of the city), with their private boarders and day scholars, settled down in their usurped position on the Gaunts, at the foot of the Bullock Park, now Park Street. From this period the free scholars often varied from one to four,- - the latter was their number in $183 \mathrm{I}$, soon after which, under the Municipal Act, the school and its property was placed under the care of the charity trustees. Since then the success which has marked the onward progress of the school is its highest commendation, and by the Education Commissioners, it is now quoted as a model school. 